\title{
THE REVITALIZATION OF LOCAL WISDOM IN FORMULATING PUBLIC
}

\author{
Mukarto Siswoyo \\ Social and Political Sciences Faculty \\ Swadaya Gunung Jati University \\ Cirebon, Indonesia \\ Muksis2000@gmail.com
}

\begin{abstract}
Cirebon city as a city of culture and city of guardian has local wisdom values such as pepatah petitih (testament) of Sunan Gunung Jati. One of the most popular testaments is "ingsun titip tajug lan fakir miskin" (I entrust with the mosques and the poor) that mandates to the government of Cirebon city to realize a religious life and the welfare of society. The local visdom values is one the potentials to implement the regional autonomy, so it must be aimed to regional regulation (Perda) in order to they can color and enliven the implementation of local government in Cirebon city.
\end{abstract}

However, there are few of local visdom values that can be found in the implementation of regional regulation of Cirebon city. During the reformation era, the government has made 213 regional regulation of local visdom values but five of them are only implemented. Those are regional regulation No 9 Year 2008 on RPJPD of Cirebon city Year 2005-2025, regional regulation No 1 Year 2009 on RPJMD of Cirebon city Year 2008-2013, regional regulation No 7 Year 2013 on RPJMD of Cirebon city Year 2013-2018, regional regulation No 4 Year 2013 on the Prohibition of Circulation and Sales of Alcohol in Cirebon city, as well as regional regulation No 6 Year 2009 on the Protection of Neglected Children and Children with Special Protection in Cirebon city.

In the Perda on Local Government Budget made every year, the budget is used mostly not to Direct Expenditure. It means that Local Government Budget of Cirebon city is not received by society in general. It also shows that the government of Cirebon city and Local House of Representative (DPRD) have lack of storng political will to improve the welfare of society and overcome the poverty problem in Cirebon city in accordance with local wisdom values that represent the testament of Sunan Gunung jati. policy

Keywords - local wisdom, public policy, formulating public

\section{INTRODUCTION}

Cirebon city is known as a city of culture because it has a lot of cultural wealth, both physical and non physical. Physical cultural assets are such as palaces, arts, buildings and heritage objects, historic sites, traditional culinary, and others. While non phisical asset is such as local wisdom.

Local wisdom such as the values prevailing in a socieaty is believed as a truth, so that it becomes a reference for the society to behave in daily life. Local wisdom is a positive thing because it has good values and benefits for human life and its environmen for both natural and social environment. Therefore, local wisdom values should be conserved and kept its existance in order to remain immortal as a guide of human life in addition to religious belief. According to Suyanto (2015), local wisdom can be immortal if it is implemented in the concrete daily life as a response for the change of era. However, in the reality of Indonesia today, it can be said that our local wisdom is as inheritance which we inherited from the ancestors but we cannot implement it in the daily life so that the inheritance becomes useless to respons the change of the era.

According Suyatno (2015), local wisdom must be impemented in state policy such as the implementation of economic policy based on mutual cooperation and kinship as one of our local wisdoms. To reach that goal, state ideology (Pancasila) must be implemented in various state policies. Thus, local wisom will be effective as a weapon, not just a heritage, that equips its society to respond the change of the era.

Before it is implemented as state policies or public policies, local wisdom values must be incorporated into formulation of public policies such as legislation. In the region, local wisdom values must be incorporated into Perda as the product of law that has highest position. If local wisdom values have been incorporeted into Perda, it will enliven the implementation of it.

Cirebon city as a city of culture and guardian has local wisdom values such as pepatah petitih (testament) from Sunan Gunung Jati. One of his most polpular testaments is "Ingsun titip tajug lan fakir miskin". It is mandated to local government and DPRD of Cirebon city to realize the the government and society based on religious values and assit the poor and save the society. Local wisdom values have positive meaning to incoorprate into Perda so that the values can color and enliven the implementation of local government in Cirebon city.

\section{DISCUSSION}

\section{A. Local wisdom}

Local wisdom is the human intelligence possessed by certain ethnic groups obtained through community experience. Meaning that, local wisdom is the result of certain 
communities through their experience and it may no be experienced by other communities. Values in local wisdom will be attached strongly to a particular society because these values have been run through a long time, as long as the existence of the community (Rahyono, 2009).

Local wisdom is not the same at different place, time and tribe. This difference is caused by the challenges of nature and the different necessities of life, so that the experience in fulfilling the need of life makes the various system of knowledge from both environment and social. As one of the behaviour of human beings, local wisdom is not static but it changes over times. It depends on the order of socio-cultural that exists in the society (Rahyono, 2009).

Moendardjito (Ayatrohaedi, 1986) describes the characteristics of local wisdom as follows:

1) It can survive against external culture.

2) It has the ability to accommodate the elements of external culture.

3) It has the ability to integrate elements of external culture into indigenous cultures.

4) It has the ability to control.

5) It can give the direction to the development of culture.

In Indonesian society, local wisdom can be found in songs, proverbs, advice, slogans, ancient books embedded in everyday behavior, and so on. Local wisdom is also reflected in the longstanding behavior and habits of society. The sustainability of local wisdom will be reflected in the values prevailing within community. These values become the hold of societies that normally become an integral part of life that can be observed through their daily attitudes and behaviors. Local wisdom is also encountered in physical form such as building architecture, traditional culinary, clothing, art, and symbols. Behind these physical forms, there are profound philosophical meanings.

\section{B. The Formulation of Public Policy}

Local wisdom must be implemented in state policy, for example by applying economic policies based on mutual cooperation and kinship as one of our local wisdoms (Suyatno, 2015). The meaning of state policy or public policy according to Dye (1981) is "whatever government choose to do or not to do". Anderson (1979) said that "Public policy is what the government actually does, and not what it intends to do". While Dunn (2006) said that "public policy is essentially a choice of government actions allocated to the whole society, so that the policy is binding, have certain goals and it is always oriented towards the fulfillment of public interest".

Nugroho (2008) describes public policy or government policy as follows:

1) Government policy always has a specific purpose or is a goal-oriented action.

2) The policy contains actions or patterns of action by government officials.
3) The policy is what the government actually does. So it is not what the government intends for or statement to do.

4) Government policy is positive, meaning that it is a government decision to do something or not to do.

5) Government policy is positive based on legislation and are coercive.

Based on the opinion above, public policy consists of the action done by the government to solve the problem that is establihed under the legislation. It means that public policy is coercive to be obeyed by the citizen. It is in line with the opinion of Winarno (2011), he said that "Public policy has the nature of 'coercion' which is potentially legitimate. This coercion is not had by the policy made by private organzation, meaning that public policy demands a wide range of society. This last statement distinguishes public policy from other policies".

Anderson (1979) said that the public policy process consists of five steps: (1) problem formulation, (2) formulation, (3) adoption, (4) implementation, and (5) evaluation. Winarno (2011) also said that public policy is a systematic process through the stages of (1) preparing the policy agenda, (2) policy formulation, (3) policy adoption, (4) policy implementation, and (5) valuation Policy.

From both opinions above, one of the important process of public policy is formulation of public policy. The formulation of public policy is the first procces that will determine the next proccess of public policy. Therefore, the formulation of public policy is important process that will determine the whole proccess of public policy.

According to Nugroho (2008), the formulation of public policy is the core of public policy because the limits of the policy will be formulated. It must be realized that public policy is aimed at intervening public life to improve public life. So the core of public policy is the government's "intervention" to improve a situation.

Public policy is formulated by officials or institutions from the central to the local level. The public policy of the Law is formulated jointly by the President with House of Representative, the Government Regulation is formulated by the Government, the Presidential Regulation and Decree is formulated by the president, regional regulation is formulated jointly by the head and DPRD, the regulation and decree are formulated by the head of region.

According to Anderson (Winarno, 2011), there are several influential values in the formulation of the policy are: 1) political values, 2) organizational values, 3) personal values, 4) policy values, and 5) ideological values

\section{The Penetration of Local Wisdom Values in Regional Regulation of Cirebon City}

Cirebon city is known as the City of Culture because it has a lot of cultures such as local wisdom. Local wisdom is a local cultural wealth that contains wisdom of life, philosophy, point of view, ethics, norms, and morality. Local wisdom is substantially positive because it contains good values and is 
beneficial to human life as well as the environment. Therefore, local wisdom must be preserved its existence and sustainability.

Cirebon local wisdom value that is well known is Sunan Gunung Jati's testament "Ingsun titip tajug lan fakir miskin". The testament contained two very valuable values for the Government of Cirebon city and DPRD as local government. Those are:

1) "ingsun titip tajug" contains a meaning that the government of Cirebon city and DPRD must run the local government and society life based on religious values and they should prosper the mosque.

2) "ingsun titip fakir miskin" contains a meaning that the government of Cirebon city and DPRD must assist the poor and save the society.

Suyatno (2015) argued that a wisdom must be implemented in the state policy or public policy including local government policy. In order to local wisdom values can be implemented, it should be incoorporated in the formulation of public policy in Cirebon city such as in Perda of Cirebon city.

During the 17 years since reformation era (in 1999) until 2016, the government of Cirebon city and have compiled 213 regulations or an average of 12 perda per year, with details as follows:

Table 1 Total of Regional Regulation of Cirebon City Year 1999-2016

\begin{tabular}{|l|l|l|l|l|l|}
\hline No. & Year & $\begin{array}{l}\text { Total of Regional } \\
\text { Regulation }\end{array}$ & No. & $\begin{array}{l}\text { Ye } \\
\text { ar }\end{array}$ & $\begin{array}{l}\text { Total of Regional } \\
\text { Regulation }\end{array}$ \\
\hline 1. & 1999 & 7 & 10. & $\begin{array}{l}20 \\
16\end{array}$ & 10 \\
\hline 2. & 2000 & 8 & 11. & $\begin{array}{l}20 \\
15\end{array}$ & 16 \\
\hline 3. & 2001 & 14 & 12. & $\begin{array}{l}20 \\
14\end{array}$ & 16 \\
\hline 4. & 2002 & 17 & 13. & $\begin{array}{l}20 \\
13\end{array}$ & 10 \\
\hline 5. & 2003 & 9 & 14. & $\begin{array}{l}20 \\
12\end{array}$ & 16 \\
\hline 6. & 2004 & 15 & 15. & $\begin{array}{l}20 \\
11\end{array}$ & 14 \\
\hline 7. & 2005 & 8 & 16. & $\begin{array}{l}20 \\
10\end{array}$ & 10 \\
\hline 8. & 2006 & 6 & 17. & $\begin{array}{l}20 \\
09\end{array}$ & 9 \\
\hline 9. & 2007 & 10 & 18. & 20 & 18 \\
\hline \multicolumn{2}{|l|}{ Total = 213 }
\end{tabular}

Source : JDIH of Cirebon city, 2017

The question is how far is the penetration of local wisdom values of Sunan Gunung Jati's testament in Perda of Cirebon city since reformation era until 2016 ?

As mentioned earlier, the local wisdom of "Ingsun titip tajug" bequeathes the Government of Cirebon city to run the local government based on religious values. This religious aspect has been reflected in the vision of Cirebon City in 2008-2013 and 2013-2018 "RAMAH" (Religious (Religius), Safe (Aman), Progress (Maju), Aspirative (Aspiratif), Green
(Hijau)). The Vision of Cirebon City 2013-2018 has been proclaimed in the Regional Medium Term Development Plan (RPJMD) of Cirebon Year 2013-2018, namely: "The realization of Cirebon City of RAMAH in 2018". RPJMD of Cirebon city in the year 2013-2018 is stipulated in Perda No. 7 of 2013.

The vision statement of Cirebon City in Perda No. 7 of 2003 has five main words that describe the condition that Cirebon city wants to achieve by the end of 2018, those are:

1) Religious, meaning that the government and the society of Cirebon City in carrying out activities, both in family, neighboring and daily work, always based on the norms and rules of the religion.

2) Safe, meaning that the city is free from various dangers that interfere safety and dicipline.

3) Progress, meaning that a city develops in a better direction in various areas of life and has a high competitiveness.

4) Aspirative, meaning that a city is based on the aspirations of society.

5) Green, meaning that a city is lush, cool, clean, and beautiful.

To realize the vision, the mission of Cirebon city is established as follows:

1) Realizing the government apparatus and the society of Cirebon City religiously.

2) Increasing the integrity and professionalism of the apparatus and revitalizing effective and efficient institutions towards good governance, trustworthiness, cleanliness, and free from coruption, collusion and nepotism.

3) Improving the quality of security and public dicipline.

4) Improving the quality of Cirebon city's resources in education, health, economic and social sectors for the welfare of society.

5) Increasing community participation in development.

6) Improving the quality of balance and environmental preservation

Perda on Medium-Term Development Plan (RPJMD) of Cirebon city in the Year 2013-2018 which contains the vision "religious" as the manifestation of local wisdom values of Sunan Gunung Jati. That is "Ingsun Titip Tajug". In other words, local wisdom values has been incoorporated into Perda. The vision "Religius" in the "RAMAH" has already listed in the previous Perda:

1) Perda No 1 Year 2009 on Medium-Term Development Plan (RPJMD) of Cirebon city in the Year 2008-2013.

2) Perda No 9 Year 2008 on Long Term Development Plan (RPJPD) of Cirebon city in the Year 2005-2025 
The vision of "Religius" in the three regional regulations (Perda No 7 of 2013, No 1 of 2009, and No 9 of 2005) is big lip because the previoous vision did not include the vision of "Religius" but " BERINTAN" (Clean (Bersih), Beautiful (Indah), Orderly (Tertib), Safe (Aman)).

As the follow up of the vision of "Religius", the government of Cirebon city and the DPRD of Cirebon city set Perda No 10 Year 2013 on the Education of Diniyah Takmiliyah. The Consideration of the stipulation of this regulation is:

1) Diniyah Takmiliyah is a Non-Formal Religious Education as a supplement to religious education to improve faith and devotion of learners in primary and secondary education.

2) The Implementation of Diniyah Takmiliyah Education needs to be done in a planned and coordinated so that the realization of education and knowledge of Islam is adequate and quality.

In article 4 of Perda is affirmed that Diniyah Takmiliyah Education serves to:

1) Fulfill the community's need for additional Islamic religious education for learners at primary and secondary education level.

2) Provide guidance in the implementation of the practice of Islamic teachings.

Based on the explanation above, Diniyah Takmiliyah Education is very important to realize the religious learners from basic education to secondary education. Nevertheless, the implementation of the Diniyah Takmiliyah Education Regulation is ineffective because it is not working properly. One of the causes is the provision of article 12, the participation of Diniyah Takmiliyah Education is not mandatory as seen from the words "in order" that is "Learners at the level of basic and secondary education that are Muslim are encouraged to study in Diniyah Takmiliyah Education".

In addition to the Regulation No. 10 of 2013 on Diniyah Takmiliyah Education, in order to carry the vision of "Religius", the Government of Cirebon city with DPRD of Cirebon city also has set Perda No. 4 of 2013 on Prohibition of Circulation and Sales of Alcoholic Beverages in Cirebon City. The consideration of the stipulation of this regulation is because alcohol is a product that can reduce the health and morals of the nation and contrary to the vision of the realization of Cirebon city "RAMAH" in 2018, so it is necessary to ban the distribution and sale of alcoholic beverages in Cirebon city.

In the article 3 of the regional regulation, it is affirmed that alcholic baverages are grouped into the following categories:

1) Alcoholic Beverages class $\mathrm{A}$ is alcoholic beverages with ethanol content $(\mathrm{C} 2 \mathrm{H} 5 \mathrm{OH})$ above $1 \%$ (one percent) up to $5 \%$ (five percent).

2) Group $B$ alcoholic beverages are alcoholic beverages with ethanol $(\mathrm{C} 2 \mathrm{H} 5 \mathrm{OH})$ content of more than $5 \%$ (five percent) to $20 \%$ (twenty percent).
3) Group $\mathrm{C}$ alcoholic beverages are alcoholic beverages with ethanol $(\mathrm{C} 2 \mathrm{H} 5 \mathrm{OH})$ content of more than $20 \%$ (twenty percent) to $55 \%$ (fifty five percent).

4) Other alcoholic beverages.

In article 4, it is affirmed that it is stipulated that every person and /or legal entity is prohibited from producing, consuming, serving, storing, selling and/or distributing alcoholic beverages, either class $\mathrm{A}$, class $\mathrm{B}$, class $\mathrm{C}$, including beverages except for certain religious activities. Whereas article 5 states that all classifications and categories of alcoholic beverages as referred to in Article 3 are confiscated and destroyed.

Based on the above description, it is clear that Perda No. 4 of 2013 on the Prohibition of Distribution and Sales of Alcoholic Beverages in Cirebon City will support the vision of "Religius" in Cirebon city. Nevertheless, the implementation of Perda is still far from expectations, partly due to the lack of law enforcement to the violators of the law.

The local wisdom values as the testament of Sunan Gunung Jati "Ingsun titip fakir miskin" entrust to the government of Cirebon city to proper the sociey and assist the poor. The substance of local wisdom "Ingsun titip fakir miskin" is stated in the vision "Progress". "Progress" means that a city that develops in a better direction in various areas of life and has a high competitiveness compared with the progress of other cities in the region and national.

The vision "Progress" is one of the visions of Cirebon city, as it is explained in the vision of Cirebon city "RAMAH". The vision of "prorgess" is stated in Perda No 9 Year 2008 on the Long-Term Development Plan (RPJMD) of Cirebon city in the Year 2005-2025, Perda No 1 Year 2009 on the MediumTerm Development Plan (RPJMD) of Cirebon city in the Year 2008-2013, and Perda No 7 Year 2013 on RPJMD of Cirebon city in the year 2013-2018. The vision "Progress" is one of the progresses in welfare of society.

However, the vision "Progress" in the context of progressing the welfare of society has not realized. It can be seen from the number of Social Welfare Problems (PMKS) in Cirebon city as it is displayed below:

Table 2. Number of Social Welfare Problem (PMKS) Cirebon city in the Year 2015

\begin{tabular}{|c|l|l|l|}
\hline No. & Kind of PMKS & Total & $\%$ \\
\hline 1. & $\begin{array}{l}\text { Children ( neglacted baby, naughty } \\
\text { persons, disability, homeless) }\end{array}$ & 2.082 & 7,44 \\
\hline 2. & Woman with unstable social economic & 5.332 & 19,03 \\
\hline 3. & Neglacted old peope & 1.009 & 3,60 \\
\hline 4. & Immoral & 72 & 0,25 \\
\hline 5. & Bummer \& Beggar & 325 & 1,16 \\
\hline 6. & Victims of Drug Use & 211 & 0,75 \\
\hline 7. & Family of the poor & 15.469 & 55,18 \\
\hline 8. & Not eligible house & 2.925 & 10,43 \\
\hline 9. & People in disaster area & 205 & 0,73 \\
\hline 10. & People with HIV / AIDS & 400 & 1,43 \\
\hline Jumlah & $\mathbf{2 8 . 0 3 0}$ & $\mathbf{1 0 0 , 0 0}$ \\
\hline
\end{tabular}

Source: Dinsosnakertrans of Cirebon city, 2016 
The table above shows that $65 \%$ more PMKS are coming from poor families and families with not eligible house. According to the author, this condition is very ironic because Cirebon city is well known as "City of guardian" with the testament of Sunan Gunung Jati "Ingsun titip fakir miskin". Thus, one of the local wisdom values is no realized in the daily life of society in Cirebon city that should be able to minimize the number of the poor.

Based on the author's exploration through the regional regulations of Cirebon city made from 1999 until 2016. The author found one regional regulation related to the effort of improving the welfare of society. That is Perda No 6 Year 2009 on Protection of Neglected Children and Children with Special Protection in Cirebon City.

In addition to that regulation, the efforts of the Government of Cirebon city to improve the welfare of society are also visible from the regulation on Regional Budget (APBD) of Cirebon city made every year. In the Regional Regulations on APBD, the partiality of the Budget to society (pro to people) can be seen from the size of the Direct Expenditure (Expenditure Development/Public Expenditure). While the alignment of APBD to the bureaucracy (pro bureaucracy) can be seen from the amount of Indirect Expenditure (Routine expenditure). Direct Expenditure shows a pro-people budget, while Indirect Expenditure shows a probureaucratic budget.

The percentage of Direct Expenditure and Indirect Expenditure in the Regonal Budget of Cirebon City for the last five years (2013-2017) can be seen in the table below:

Table 3. Percent of Direct and Indirect Expenditure In the Regional Budget of Cirebon City in theYear 2013-2016

\begin{tabular}{|c|c|c|c|c|}
\hline No. & $\begin{array}{l}\text { Year of } \\
\text { Budget }\end{array}$ & Kind of Expenditure & Total & $\%$ \\
\hline \multirow{3}{*}{1.} & \multirow{3}{*}{2017} & 1. Direct Expenditure & $711.210 .500 .491,00$ & $52,3 \%$ \\
\hline & & 2. Indirect Expenditure & $648.384 .278 .809,00$ & $47,7 \%$ \\
\hline & & Total of Expenditure & $1.359 .594 .779 .300,00$ & $100,0 \%$ \\
\hline \multirow{3}{*}{2.} & \multirow{3}{*}{2016} & 1. Direct Expenditure & $890.343 .848 .849,00$ & $57,1 \%$ \\
\hline & & 2. Indirect Expenditure & $669.371 .254 .371,00$ & $42,9 \%$ \\
\hline & & Total of Expenditure & $1.559 .715 .103 .220,00$ & $100,0 \%$ \\
\hline \multirow{3}{*}{3.} & \multirow{3}{*}{2015} & 1. Direct Expenditure & $615.645 .050 .329,00$ & $49,1 \%$ \\
\hline & & 2. Indirect Expenditure & 637.615.106.671,00 & $50,9 \%$ \\
\hline & & Total of Expenditure & $1.253 .260 .157 .000,00$ & $100,0 \%$ \\
\hline \multirow{3}{*}{4.} & \multirow{3}{*}{2014} & 1. Direct Expenditure & $474.551 .448 .393,00$ & $44,8 \%$ \\
\hline & & 2. Indirect Expenditure & $584.070 .992 .741,00$ & $55,2 \%$ \\
\hline & & Total of Expenditure & 1.058.622.441.134,00 & $100,0 \%$ \\
\hline \multirow{3}{*}{5.} & \multirow{3}{*}{2013} & 1. Direct Expenditure & $439.861 .177 .207,00$ & $46,9 \%$ \\
\hline & & 2. Indirect Expenditure & $498.925 .165 .945,00$ & $53,1 \%$ \\
\hline & & Total of Expenditure & 938.786.343.152,00 & $100,0 \%$ \\
\hline
\end{tabular}

Source: Regional Budget of Cirebon City, 2017

Based on the above table it is known that in the last five years (2013-2016), the total amount of expenditure in the Cirebon city budget continues to increase. However, during those five years, the percentage of Direct Expenditure is always smaller than Indirect Expenditure, except in 2016 where Direct Expenditure is higher than Indirect Expenditure, but Direct Expenditure is allocated for the construction of 8floor Setda building, not for the benefit of the society.

\section{CONCLUSION}

Based on the above description, the local wisdom values form of Sunan Gunung Jati's testament "Ingsun titip tajug lan fakir miskin" is incoorporated into regional regulation of Cirebon city very little. From 213 regulations made by the government during the reformation era (1999-2016), there are five local wisdom values that are incooporate into regional regulation. Those are Regulation No. 9 Year 2008 on RPJPD of Cirebon City in the Year 2005-2025, regional Regulation No 1 Year 2009 on RPJMD of Cirebon City in the Year 20082013, Regional Regulation No 7 of 2013 on RPJMD of Cirebon City Year 2013-2018, Regional Regulation No 4 of 2013 on the Prohibition of Circulation and Sales of Alcoholic Beverages in Cirebon City, and Regional Regulation No 6 Year 2009 on Protection of Neglected Children and Children with Special Protection in Cirebon city

The implementation of local government in Cirebon city has not reflected the religious aspect and the welfare of society. In religious aspect, Cirebon city as a city of guardian has not shown its religiousness. The society still focuses on the materialistic especially for youth. Nowadays, In Cirebon city, it is commonly found such as secularism, hedonism, night club, free sex, prostitution, crime, and other social problems. This is very ironic for Cirebon city because as long as Cirebon is well known as a city of guardian. It should be found the religious behaviour as mandated by Sunan Gunung Jati in his testament "Ingsun titip tajug lan fakir miskin".

While in the aspect of society welfare, the number of PMKS in Cirebon City in the year 2016 even increased. From 28,030 people, It becomes 114.261 people or almost one third of population of Cirebon city. From the total number of PMKS, the number of the poor dominates that reached 109,250 people or about $30 \%$ of the total population of Cirebon City. The number of the poor is 109,250 people in 2016. It increase more than 2015 or 15,469 people. In the other sides, economic growth and investment in Cirebon city continues to grow rapidly from year to year.

The number of the poor increased almost one third of the population of Cirebon city.It is very ironic because Cirebon city has local wisdom values as mandated by Sunan Gunung Jati in his testament "Ingsun titip tajug lan poor fakir". The Increasing the number of the poor shows that the government of Cirebon city has not succeeded in formulating, implementing, and revitalizing local wisdom values of Sunan Gunung Jati's testament in the implementation of local government based on regional autonomy. Whereas the purpose of regional autonomy is to accelerate the improvement of society welfare.

Meanwhile, in the Regional Regulations on regiobal budget made annually, regional expenditure is mostly used for Indirect expenditure. This shows that the budget of Cirebon city is not pro to society. It also shows the government of Cirebon city and its local house of representative have lack of political will to improve the welfare of society and overcome poverty in Cirebon city in accordance with local wisdom values as mandated by Sunan Gunung Jati in his testament. Therefore, in the coming years, it is expected that the regional regulation will contist of local wisdom values "Ingsun titip 
tajug lan fakir miskin" in order to local wisdom values as wealth of local culture can color and enliven the the implementation of local government In Cirebon city.

\section{References}

[1] Anderson, James E. 1979. Public Policy Making. New York: Holt Rinehart and Winston

[2] Ayatrohaedi. 1986. Kepribadian Budaya Bangsa (Llokal Genius). Jakarta: Pustaka Jaya

[3] Dunn, Wiliiam N. 2006. Pengantar Analisis Kebijakan Publik. Yogyakarta: Gajah Mada University Press
[4] Dye, Thomas R. 1981. Understanding Public Policy. Englewood Cliff: Prentice Hall

[5] Heryani, Ani. 2010. Paradigma Kebijakan Publik. Bandung: Unpad Press

[6] Islamy, M. Irfan. 2003. Prinsip-prinsip Perumusan Kebijaksanaan Negara. Jakarta: Bumi Aksara

[7] Nugroho, Riant. 2008. Kebijakan Publik. Formulasi, Implementasi, dan Evaluasi. Jakarta:PT. Elex Media Komputindo

[8] Rahyono, F.X. 2009. Kearifan Budaya dalam Kata. Jakarta: Wedatama Widyasastra.

[9] Suyatno, Suyono. 2015. Revitalisasi Kearifan Lokal Sebagai Upaya Penguatan Identitas Keindonesiaan. http://badanbahasa. kemdikbud.go.id/laman-bahasa/artikel/1366

[10] Winarno, Budi. 2011. Kebijakan Publik. Teori, Proses, dan Studi Kasus. Yogyakarta: CAPS 